\title{
Article/Artigo
}

\section{Epidemiological aspects of human and canine visceral leishmaniasis in Montes Claros, State of Minas Gerais, Brazil, between 2007 and 2009}

\author{
Aspectos epidemiológicos da leishmaniose visceral humana e canina em Montes Claros, \\ Estado de Minas Gerais, Brasil, entre 2007 e 2009
}

\section{Patrícia Fernandes do Prado ${ }^{1}$, Marília Fonseca Rocha ${ }^{1,2}$, Joel Fontes de Sousa ${ }^{2}$, Dênio Iuri Caldeira ${ }^{2}$, Gustavo Fontes Paz $^{3}$ and Edelberto Santos Dias ${ }^{3}$}

\begin{abstract}
Introduction: Visceral leishmaniasis (VL) is an expanding zoonosis in Brazil and is becoming urbanized in several Brazilian regions. This study aims to describe the epidemiological features of human and canine VL in the municipality of Montes Claros, State of Minas Gerais, by focusing on their spatial distribution. Methods: Data concerning human cases and reactive dogs for VL from 2007 to 2009 were obtained from the Information System for Disease Notification (SINAN) and from reports of the local Centro de Controle de Zoonoses (CCZ), respectively. The addresses of human and canine cases have been georeferenced and localized in thematic maps, allowing their spatial visualization as well as the identification of areas at risk of VL transmission. Results: Ninety-five cases of human VL were reported in the period. The 0-9-year-old age group (48.4\%) was the most affected, within which the majority consisted of male patients (64\%). Of the samples collected for the canine serological survey, 2,919 (6.3\%) were reactive to $\mathrm{VL}$. The spatial localization of these cases shows that the disease was scattered in the urban area of the municipality. Areas showing a higher dissemination risk were concentrated in the central, northwestern, and southern regions of the city. Conclusions: Identifying the areas most at risk in urban Montes Claros may help guide actions toward local epidemiological vigilance and control.
\end{abstract}

Keywords: Visceral leishmaniasis. Epidemiology. Spatial distribution.

\section{RESUMO}

Introdução: A leishmaniose visceral (LV) é uma zoonose em expansão no Brasil e está se tornando urbana em várias regiões brasileiras. Este estudo descreve aspectos epidemiológicos da LV humana e canina no município de Montes Claros, Minas Gerais, com enfoque na distribuição espacial de sua incidência. Métodos: É um estudo epidemiológico descritivo, que utiliza dados relativos à casos humanos e soro-positividade canina para LV, obtidos do Sistema de Informação de Agravos de Notificação (SINAN) e de relatórios do Centro de Controle de Zoonoses (CCZ) local. Os endereços dos casos estudados foram georreferenciados e localizados em mapas temáticos que permitem sua visualização espacial, bem como a identificação de áreas de risco de transmissão da doença. Resultados: A leishmaniose visceral humana e canina mostrou ampla distribuição espacial em Montes Claros. No período entre 2007 a 2009, foram notificados 95 casos humanos da doença. O grupo etário entre 0 e 9 anos foi o mais afetado (48.4\%) com maior prevalência no sexo masculino (64\%). Dentre as amostras caninas coletadas para investigação sorológica, 2.919 (6,3\%) foram reativas para LV. A localização espacial desses casos mostra que a doença está disseminada na área urbana do município. As áreas com maior risco de disseminação concentraram-se nas regiões central, noroeste e sul da cidade. Conclusões: A identificação das áreas de maior risco na zona urbana de Montes Claros poderá guiar as ações de vigilância epidemiológica e de controle locais. Palavras-chaves: Leishmaniose visceral. Epidemiologia. Distribuição espacial.

1. Programa de Pós-Graduação em Ciências da Saúde, Universidade Estadual de Montes Claros, Montes Claros, MG. 2. Centro de Controle de Zoonoses, Secretaria Municipal de Saúde de Montes Claros, Montes Claros, MG. 3. Laboratório de Leishmanioses, Centro de Pesquisas René Rachou, Fundação Oswaldo Cruz, Belo Horizonte, MG.

Address to: Dr. Edelberto Santos Dias. Lab. Leishmanioses/CPqRR/FIOCRUZ. Av. Augusto de Lima 1715, 30190-002 Belo Horizonte, MG, Brasil.

Phone: 5531 3349-7700; Fax: 5531 3295-3115

e-mail: edel@cpqrr.fiocruz.br

Received in 28/01/2011

Accepted in 05/04/2011

\section{INTRODUCTION}

Visceral leishmaniasis (VL) is thoroughly disseminated all over the world and is endemic in approximately 72 countries ${ }^{1}$, mainly in the tropical and subtropical regions of Asia, the Middle East, Africa, Central America, and South America. The estimated incidence of VL reaches 500,000 new cases annually ${ }^{2}$, and the disease may turn into an anthroponosis or anthropozoonosis when humans act as reservoirs. VL is a systemic and serious disease that can affect children, youth, adults, and immunodepressed persons. It is characterized bylong-lasting fever and other symptoms. If not treated, this disease becomes fatal within one or two years after its symptomatology appears ${ }^{3}$.

The etiological agents of VL are protozoa of the Trypanosomatidae family, Leishmania genus; three species of which may cause the disease: Leishmania (Leishmania) donovani in Asia and Africa; Leishmania (L.) infantum in Asia, Europe, and Africa; and Leishmania (L.) infantum chagasi in the Americas ${ }^{4}$.

The vectors transmitting the disease are phlebotomine sand flies (Diptera: Psychodidae: Phlebotominae); and two species are considered as vectors in Brazil: Lutzomyia longipalpis (Lutz \& Neivai, 1912) and Lutzomyia cruzi (Mangabeira, 1938), especially the former 5 .

Dogs (Canis familiaris) are identified as the main domestic VL reservoir; thus, the detection of infected animals is crucial in VL control. Even when they do not display any clinical symptom of the disease, the animals may act as a source of parasite infection for phlebotomine sand flies ${ }^{6}$.

Among the countries in the Americas, Brazil presents the greatest VL endemicity. The disease occurs in all five Brazilian regions, with outbreaks in medium-sized and large urban centers ${ }^{5}$. Once considered predominantly rural, VL has undergone an urbanization process associated with changes in the behavior of the transmitting vector, environmental degradation, and the migration of human and canine populations to larger urban centers ${ }^{7,8}$. 
The strategies recommended by the National Visceral Leishmaniasis Control Program of Brazil are based on a set of measures, such as precocious diagnosis and treatment of human cases, canine serological investigation and culling of all seropositive dogs, systematic insecticide spraying in domiciles and peridomiciles, community education programs, and environmental management ${ }^{9}$. These measures must be taken together to be effective in reducing the incidence of the disease.

Incorporating new VL control methodologies in endemic and nonendemic municipalities constitutes a new approach to the problem, which may help to determine more specific and direct control measures for each one. Knowing the specific epidemiological features of an area is crucial in making distinct and adequate measures for each different situation?. The technological progress achieved since the 1990s has made it possible to develop and use new tools for describing health conditions, such as maps that allow observing the spatial distribution and risk areas. One such tool is geoprocessing, which incorporates several other technologies for geographical data treatment and handling ${ }^{10}$. Geoprocessing has been used in VL planning and control actions ${ }^{10-14}$. Data are collected, treated, handled, and presented as spatial data by means of geographic information systems (SIG) $)^{15,16}$.

VL is endemic in the municipality of Montes Claros, State of Minas Gerais, where the disease constitutes a serious public health problem. There are a number of human cases of VL, and both the population density of the transmitting vector and the canine prevalence are high ${ }^{17}$. The aim of this paper is to describe the epidemiological features of human and canine VL in Montes Claros from 2007 to 2009 in terms of the vigilance surveillance and control actions that were implemented in the period.

\section{METHODS}

\section{Area of study}

Montes Claros (16043'41'S, 43051'54"W) is located in the Northern region of the State of Minas Gerais at an altitude of $638 \mathrm{~m}$. The municipality extends over an area of $4,135 \mathrm{~km}^{2}$ and has 363,227 inhabitants ${ }^{18}$. It has a semi-humid tropical climate with a prolonged dry season.

\section{Human cases}

Confirmed cases of human VL from 2007 to 2009 were analyzed and registered at the Information System for Disease Notification (SINAN $)^{19}$, which is made available by the epidemiological vigilance service of the Municipal Health Department.

The incidence coefficients and VLlethality per 100,000 inhabitants were estimated based on the records of confirmed disease cases and deaths; the population estimates for each year were provided by the Brazilian Geography and Statistics Institute (IBGE) ${ }^{18}$.

\section{Canine cases}

Data on serologically reactive dogs for VL in the period of April 2007 to May 2009, as well as the amount of euthanized animals and the number of implemented actions on VL vigilance and control were supplied by the local Centro de Controle de Zoonoses (CCZ). The ELISA (enzyme-linked immunosorbent assay) was the selection test used in the canine survey, which was later confirmed by indirect immunofluorescence reaction (IFR), as recommended by the Brazilian Ministry of Health?

\section{Georeferenced data}

The map of Montes Claros was provided by the City Hall in DWG file format (AutoCAD program) and converted into Shapefile (shp) using the Trackmaker and TerraView version 3.14 computer programs. The addresses of human and canine cases were georeferenced by means of Garmin GPSMAP 60CSx. The final map was prepared by combining the data using ArcGIS 3.2 and Mapinfo 7.5. The kernel map for distributing the density of canine cases was used in the Mapinfo program.

For 2009, four reported cases were not georeferenced: one had an address that could not be found, one was considered an imported case by the epidemiological surveillance agents, and two were from rural areas. Besides, when two or more cases shared the same address, they were georeferenced as a single point.

\section{RESULTS}

For the whole period under study, 95 VL human cases were reported in the municipality of Montes Claros, for an average of 32.3 cases per year. A total of six deaths were reported: four in 2007, which revealed an increased lethality coefficient in the series, followed by one death each in 2008 and 2009 (Table 1). More males were affected (64\%) in the whole period of study. As for the age groups, the 0-9-yearold group was the most affected (48.4\%), followed by those 20-39 (20\%), 40-59 (15.8\%), 10-19 (9.5\%), and >60 (6.3\%) years old.

As for the canine serological investigation, 46,337 samples were collected, of which 2,919 (6.3\%) were VL-reactive. Table 2 shows the annual canine samples analyzed, including the seropositivity prevalence in the series and the amount of euthanized dogs.

Figure 1 shows the human and canine cases in the study period, allowing certification of the large-scale distribution and overlapping of both occurrences. It is worth noting that canine seropositivity coexisted with human disease in all local areas. By visualizing the risk areas for $\mathrm{VL}$ within that municipality as registered in the kernel map, it can be noted that the areas showing a higher concentration of cases were localized in the central, northwestern, and southern regions of the urban area of Montes Claros.

TABLE 1 - Descriptive data of human VL cases in the urban area of Montes Claros, State of Minas Gerais, Brazil, between 2007 and 2009.

\begin{tabular}{|c|c|c|c|c|c|}
\hline \multirow[b]{3}{*}{ Year } & \multirow{3}{*}{$\begin{array}{l}\text { Estimated } \\
\text { human } \\
\text { population }\end{array}$} & \multirow{2}{*}{\multicolumn{2}{|c|}{ VL occurrences (n) }} & \multirow{2}{*}{\multicolumn{2}{|c|}{ Coefficients }} \\
\hline & & & & & \\
\hline & & cases & deaths & incidence $^{*}$ & lethality (\%) \\
\hline 2007 & 352,384 & 27 & 4 & 7.6 & 14.8 \\
\hline 2008 & 358,271 & 35 & 1 & 9.7 & 2.8 \\
\hline 2009 & 363,227 & 33 & 1 & 9.0 & 3.0 \\
\hline Total & - & 95 & 6 & - & - \\
\hline
\end{tabular}

*per 100,000 inhabitants, VL: visceral leishmaniasis.

TABLE 2 - Canine serological survey for VL in Montes Claros, State of Minas Gerais, Brazil, between 2007 and 2009.

\begin{tabular}{lccccc}
\hline Year & $\begin{array}{c}\text { Dogs } \\
\text { examined }\end{array}$ & Reactive & \multicolumn{2}{c}{ Euthanized (\%) } & Prevalence (\%) \\
\hline 2007 & 14,485 & 1,041 & 937 & 90.0 & 7.1 \\
\hline 2008 & 23,884 & 1,411 & 1,186 & 84.0 & 5.9 \\
\hline 2009 & 7,968 & 467 & 358 & 76.6 & 5.8 \\
\hline Total & $\mathbf{4 6 , 3 3 7}$ & $\mathbf{2 , 9 1 9}$ & $\mathbf{2 , 4 8 1}$ & - \\
\hline
\end{tabular}

VL: visceral leishmaniasis. 


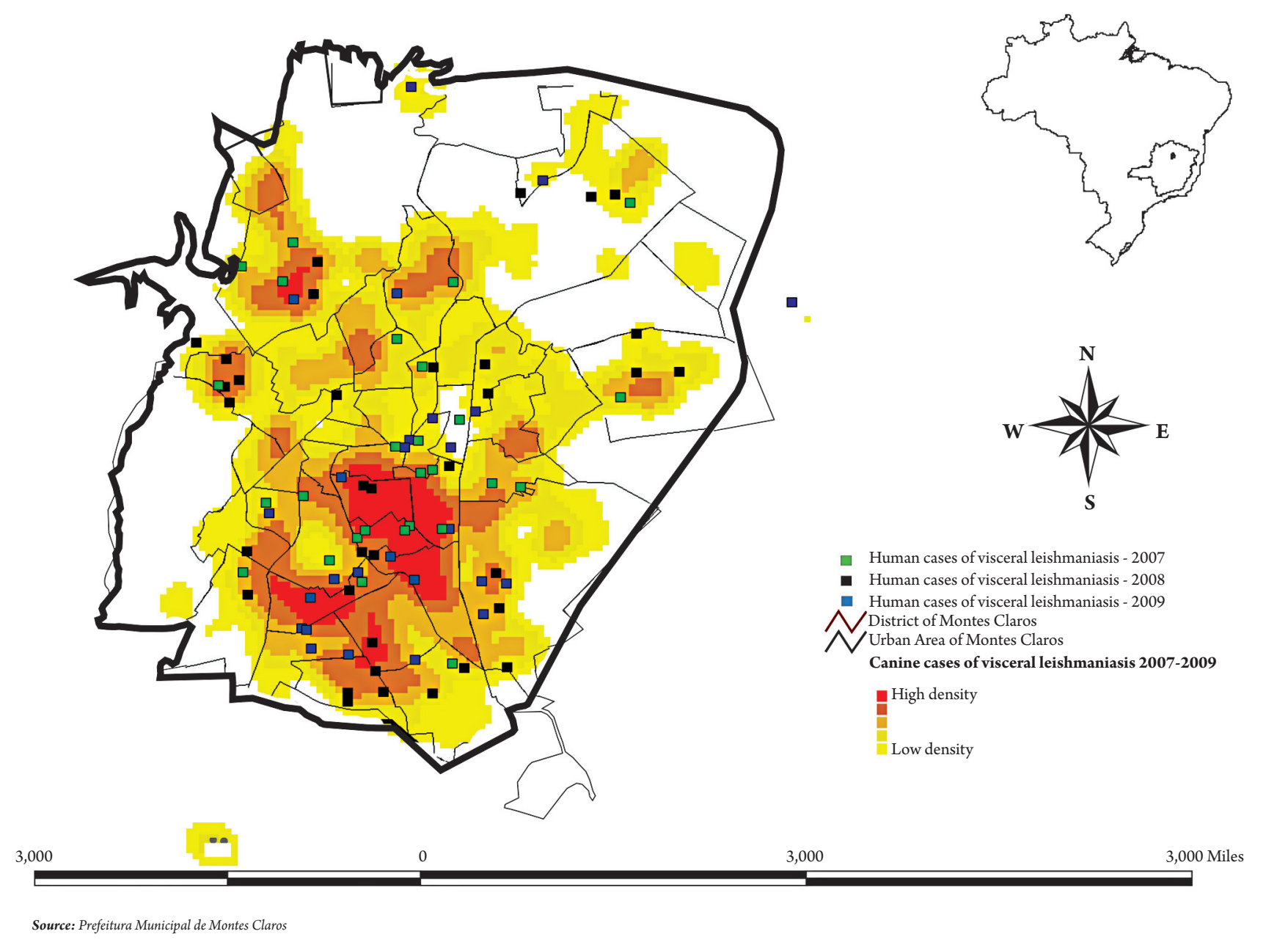

FIGURE 1 - Kernel map for canine cases of visceral leishmaniasis in Montes Claros (State of Minas Gerais, Brazil) from 2007 to 2009 . The number of human cases of visceral leishmaniasis per year in the period studied is also indicated.

\section{DISCUSSION}

Montes Claros is one of the Brazilian municipalities where VL has been converted into an urban endemic disease. It has been classified as an intensive transmission area, in accordance with the stratification proposed by the Brazilian Ministry of Health ${ }^{9}$. Its characteristic urban environment is propitious to VL occurrence, with a climate and topography favorable for vector proliferation, in addition to the existence of many extremely poor dwellings lacking basic water and sewage facilities. In some areas, accumulated organic matter ${ }^{17}$ becomes a significant risk factor for the disease. The VL incidence and lethality coefficients registered in Montes Claros have been above the national average in recent years, with the former reaching 1.9 cases per 100,000 inhabitants and the latter representing 5.5\% of all deaths ${ }^{5}$. In 2003 and 2004, the municipality faced an epidemic surge with 44 and 68 cases of human cases of VL, respectively. These numbers corresponded to incidences of 13.5 and 20.6 cases per 100,000 inhabitants, accounting for $9.1 \%$ and $4.4 \%$ of deaths in the respective years.

The first project designed to intensify VL control actions in Montes Claros was prepared in 2005 in compliance with the recommendations of the Ministry of Health. Such actions suggested measures toward controlling the vector and the canine reservoir, improving the treatment of human cases, environmental management actions, and educational activities. At the time, the subdivision of the urban area into 19 sectors was proposed, in accordance with the identified epidemiological and sociodemographic parameters. In that year, the risk stratification analysis showed that there were two intensive transmission areas $(n \geq 4.4$, where $n$ is the average number of human cases of VL in the last 5 years), five moderate transmission areas $(4.4<\mathrm{n} \leq 2.4)$, and 12 sporadic transmission areas $(\mathrm{n}<2.4)^{9}$.

A survey of infected animals was carried out using ELISA and IFR for the canine reservoir control, and seropositive dogs were euthanized as recommended 9 .

In order to control the vector population density, alphacipermetrine insecticide was applied in intradomiciles and peridomiciles localized in districts of moderate VL transmission as well as in districts of sporadic transmission but high canine VL prevalence. Every dwelling within urban blocks with confirmed VL human cases was also included.

The environmental management, recorded in a specific form, consisted surveying the environmental conditions of dwellings, as well as the number of residents, size of peridomiciles, vegetation (if absent, shadowy, or shadowless; accumulated organic matters on the ground, such as leaves, fruits, trunks, roots, domestic animals' feces), and number of dogs or other existing domestic animals. The dweller was advised to take preventive measures to reduce favorable environment conditions for breeding transmission vectors.

Educational health activities were developed through lectures, meetings, exhibition stands, and visits to households to give 
the population information on the disease and the relevance of environmental management, as well as to assure their involvement and participation in all control actions.

Two years later, in 2007, the stratification analysis pointed to 13 sectors showing sporadic transmission, six others of moderate transmission, and none of intensive transmission. In 2008 and 2009, three moderate transmission sectors, 16 sporadic transmission sectors, and again, no intensive transmission sectors were revealed. Notwithstanding a high death rate in 2007 (14.8\%), the years 2008 and 2009 showed significantly decreased rates of $2.8 \%$ and $3 \%$, respectively. This fact possibly reflects an increased detection of occurrences due to updated advice delivered by health professionals, together with the dissemination of information on the disease to the population, thus reducing late diagnosis, which is considered one the factors explaining VL lethality ${ }^{9}$. Figure 2 shows the annual stratification profiles of VL endemic areas in Montes Claros since the first intervention carried out in 2005.

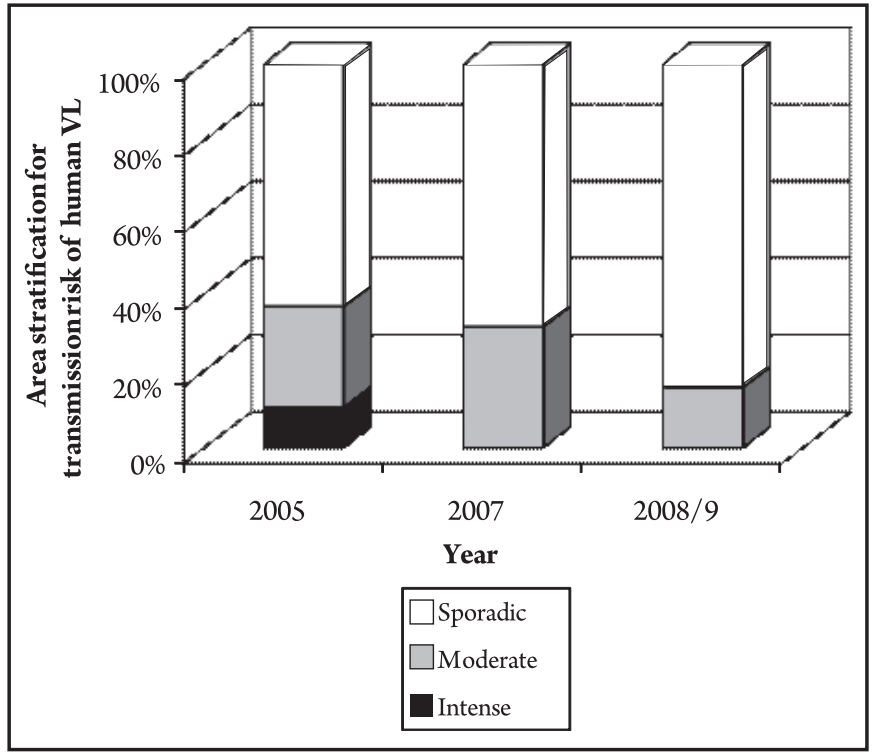

FIGURE 2 - Area stratification of transmission risk for $\mathrm{VL}$ in the urban area of Montes Claros (State of Minas Gerais, Brazil) from 2005 to 2009.

The area stratification followed the Brazilian Ministry of Health criteria ${ }^{9}$, which take into account the average number of human cases (n) per year in the last 5 years: intense $(\mathrm{n} \geq 4.4)$, moderate $(4.4<\mathrm{n} \leq 2.4)$, or sporadic $(\mathrm{n}<2.4)$. VL: visceral leishmaniasis.

Another factor associated with VL lethality is the inclusion of the disease in the list of opportunistic infections that affect groups with comorbidities and individuals infected with the human immunodeficiency virus (HIV), a population presenting an emerging highly serious clinical status for $\mathrm{VL}^{3}$. Several studies have shown the presence of asymptomatic infections by Leishmania chagasi in VL endemic areas ${ }^{20,21}$. Bearing in mind that a HIV-positive patient in a VL endemic area has 10-100 times higher risk of contracting the disease ${ }^{22}$, the HIV infection would have the effect of demasking the true incidence of Leishmania infection ${ }^{23}$. The Leishmania-HIV coinfection occurred in seven patients out of the 95 cases studied in the municipality.

In the present study, VL was more frequent in children aged 0-9 years, a similar result to that found in the literature ${ }^{5,24,25}$, although a change in this profile has been detected, with an increased number of cases in young adults ${ }^{26,27}$. The higher susceptibility of children is explained by their relative cellular immaturity, aggravated by the malnutrition usually found in endemic areas and even by higher exposure to the vector in the peridomicile ${ }^{5}$. Epidemiologically speaking, this also suggests a precocious proximity of humans to the disease vector in our environment ${ }^{5}$, a finding that corroborates the study of Monteiro et al. ${ }^{17}$, who observed that L. longipalpis was the prevalent species in both intradomiciles and peridomiciles during an entomologic survey in the municipality. Another important factor observed by these authorswas that the population density of L. longipalpis in the local area might be associated with local climate variables (accumulated rainfall, average temperature, and relative humidity of air) ${ }^{28}$.

In this study, more male individuals (64\%) were affected by VL, which is compatible with the average of $61 \%$ found in the country. The reason for this has not been completely clarified, although factors related to gender behavior, such as men's clothing and the duration and time schedule of exposure to the vector, could explain such finding.

Serologically positive dogs were scattered in the municipality, confirming the influence of this element in human disease. The serological investigation was carried out with emphasis on vigilance and control of canine reservoirs in the moderate transmission sectors. With regard to the sporadic transmission areas as of 2007, an investigation was accomplished using a sample form, and the results pointed to a disease prevalence of more than $5 \%$, confirming the need for a canine census in all sectors of the urban municipal area. This action was not possible due to operational problems, such as lack of diagnosis kits, insufficient blood collection personnel, and delayed acquisition process for equipment needed to implement the ELISA technique in the CCZ laboratory. The refusal of many owners to allow diagnosis and euthanasia of seropositive dogs constituted a hindrance to eliminating canine reservoirs. This was probably due to both insufficient knowledge of the disease, which stresses the need for educational measures, and adherence to canine treatment, which is forbidden by interministerial regulation ${ }^{29}$. This might also be the reason for the smallest percentage of euthanasia observed in 2009.

Vigilance and control of vectors have also presented operational problems, such as lack of insecticides, lack of transport for supervising activities, and shortage of trained teams for insecticide spraying. Additionally, the increased incidence of dengue in the municipality has led health authorities to give priority to measures designed to address this disease, to the detriment of the planned activities for VL control. According to the Ministry of Health ${ }^{9}$, the recommended activities for vectorial control are dependent on the epidemiological and entomological features of each locality, as chemical control should be planned for the period of vector population increase in the areas of intensive and moderate transmission. Although the municipality of Montes Claros does not have a structured entomology laboratory, a partnership with the Instituto René Rachou, Fundação Oswaldo Cruz (CPqRR/FIOCRUZ) has made it possible to establish the VL seasonality for the period 2003 to $2008^{17,28}$, and the data obtained are being used in the ongoing program of activities.

As for the environmental management strategy adopted, it is worth mentioning that Borges ${ }^{30}$ observed that the chances of contracting VL are 2.8 times greater in residences where organic matter is present because sand flies tend to set up their breeding places in environments rich in organic matter. The results found by Barata et al. ${ }^{7}$ confirm this finding. Other factors related to environment conditions cited in the literature as being favorable for the presence of vectors in the peridomicile are chicken yards, humidity, garbage, and vegetation. The attraction of chicken yards derives from their function as shelter and food source for the vector. 
As for the health educational activities, the Ministry of Health ${ }^{9}$ recommends the effective involvement of multi-professional and multi-institutional teams in articulated actions. The educational actions developed in the municipality were carried out by the educational team of the CCZ, which was composed of health surveillance and environmental technicians, although subject to the available financial and material resources. Additionally, this team is entitled to carry out activities in all control programs for endemic diseases, zoonoses, and urban plagues in the municipal urban and rural areas.

Despite the various possibilities in using a geographic information system (GIS), in this study it was used only to describe the spatial distribution of VL cases to call attention to the need for future investigations of other variables involved in the VL epidemiological scenario in Montes Claros. The largely scattered spatial distribution of the disease in this urban area is, undoubtedly, one of the greatest local public health challenges to be tackled. Several difficulties can be verified in implementing control activities in view of the insufficient human, material, and financial resources now available for carrying out the needed measures in a thorough and integrated way. However, an analysis of the historical series of VL stratification in Montes Claros shows that, even in the face of such constraints, human VL cases decreased, as reflected in the absence of intensive transmission since 2007 as well as the decreased number of moderate transmission areas. Despite the fact that integrated actions in the whole municipality have not yet been implemented, the kernel map obtained is able to point out those areas with a higher risk of VL transmission where vigilance and control actions should be given priority.

\section{ACKNOWLEDGMENTS}

To the staff of the Centro de Controle de Zoonoses (CCZ) of the Health Department of Montes Claros for their valuable collaboration; to Fernanda Cristina de Souza Paz for helping with the map; and to Dr. Consuelo Latorre Fortes-Dias (Fundação Ezequiel Dias, FUNED) for text criticisms and suggestions.

\section{CONFLICT OF INTEREST}

The authors declare that there is no conflict of interest.

\section{FINANCIAL SUPPORT}

Fundação de Amparo à Pesquisa do Estado de Minas Gerais (FAPEMIG), Fundação Oswaldo Cruz (FIOCRUZ), and Universidade Estadual de Montes Claros (UNIMONTES).

\section{REFERENCES}

1. World Health Organization. Programme for the surveillance and control of leishmaniasis. 2004 [Internet]. [cited 2010 Dec 12]. Available from: http:// www.who.int/emc/diseases/leish/index.html.

2. Desjeux P.Leishmaniasis: current situation and new perspectives. Comp Immunol Microbiol Infect Dis 2004; 27:305-318.

3. Alves WA, Bevilacqua PD. Reflexões sobre a qualidade do diagnóstico da leishmaniose visceral canina em inquéritos epidemiológicos: o caso da epidemia de Belo Horizonte, Minas Gerais, Brasil, 1993-1997. Cad Saude Publica 2004; 20:259-265.

4. Lainson R, Rangel EF. Lutzomyia longipalpis and the eco-epidemiology of American visceral leishmaniasis, with particular reference to Brazil: a review. Mem Inst Oswaldo Cruz 2005; 100:811-827.
5. Ministério da Saúde. Guia de vigilância epidemiológica. Série A. Normas e Manuais Técnicos. Brasília: Ministério da Saúde; 2009.

6. Michalsky EM, Rocha MF, Rocha-Lima ACVM, França-Silva JC, Pires MQ Oliveira FS, et al. Infectivity of seropositive dogs, showing different clinical forms of leishmaniasis, to Lutzomyia longipalpis phlebotomine sand flies. Vet Parasitol 2007; 147:67-76.

7. Barata RA, França-Silva JC, Mayrink W, Silva JC, Prata A, Lorosa ES, et al. Aspectos da ecologia e do comportamento de flebotomíneos em área endêmica de leishmaniose visceral, Minas Gerais. Rev Soc Bras Med Trop 2005; 38:421425.

8. Werneck GL. Forum: geographic spread and urbanization of visceral leishmaniasis in Brazil. Introduction. Cad Saude Publica 2008; 24:2937-2940.

9. Ministério da Saúde. Manual de Vigilância e Controle da Leishmaniose visceral Brasília: Ministério da Saúde; 2006.

10. Margonari CS. As leishmanioses no município de Belo Horizonte: estudos entomológicos e biogeográficos visando à vigilância entomológica. [Doctor thesis]. [Rio de janeiro]: Instituto Oswaldo Cruz; 2005. 158 p.

11. Machado-Coelho GLL, Assunção R, Mayrink W, Caiaffa WT. American Cutaneous Leishmaniasis in Southeast Brazil: space-time clustering Inter J Epidemiol 1999; 28:982-989.

12. Oliveira CDL, Assunção RM, Reis IA, Proietti FA. Spatial distribuition of human and canine visceral leishmaniasis em Belo Horizonte, Minas Gerais, State, Brazil, 1994-1997. Cad Saude Publica 2001; 17:1231-1239.

13. Kawa H, Sabroza PC. Espacialização da leishmaniose tegumentar na Cidade do Rio de Janeiro. Cad. Saude Publica 2002; 18:853-865.

14. Werneck GL, Maguire JH. Spatial modeling using mixed models: an ecologic study of visceral leishmaniasis in Terezina, Piauí, State, Brasil. Cad Saude Publica 2002; 18:633-637.

15. Gauy JS, Hino P, Santos CB. Spatial distribution of leprosy cases in Ribeirão Preto, Brazil, 2004. Rev Lat Am Enfermagem 2007; 15:460-465.

16. Clarke KC, McLafferty SL, Tempalski BJ. On epidemiology and geographic information systems: a review and discussion of future directions. Emerg Infect Dis 1996; 2:85-92.

17. Monteiro EM, Silva JCF, Costa RT, Costa DC, Barata RA, Paula EV, et al Leishmaniose visceral: estudo de flebotomíneos e infecção canina em Montes Claros, Minas Gerais. Rev Soc Bras Med Trop 2005; 38:147-152.

18. Instituto Brasileiro de Geografia e Estatística. Estimativas populacionais para os municípios brasileiros [Internet]. [cited 2010 July 12]. Available from: http:// www.ibge.gov.br/home/estatistica/populacao.

19. Ministério da Saúde. Sistema de Informação de Agravos de Notificação. Secretaria de Vigilância em Saúde [Internet]. [cited 2010 Dec 12]. Available from: http:// dtr2004.saude.gov.br/sinanweb/novo/.

20. Moreno EC, Melo MN, Genaro O, Lambertucci JR, Serufo JC, Andrade ASR, et al. Risk factors for Leishmania chagasi infection in an urban area of Minas Gerais State. Rev Soc Bras Med Trop 2005; 38:456-463.

21. Oliveira ALL, Paniago AMM, Sanches MA, Dorval MEC, Oshiro ET, Leal $\mathrm{CRB}$, et al. Asymptomatic infection in family contacts of patients with human visceral leishmaniasis in Três Lagoas, Mato Grosso do Sul State, Brazil. Cad Saude Publica 2008; 24:2827-2833.

22. Daher EF, Fonseca PP, Gerhard ES, Leitão TM, Silva Júnior GB. Clinical and epidemiological features of visceral leishmaniasis and HIV co-infection in fifteen patients from Brazil. J Parasitol 2009; 95:652-655.

23. Dujardin JC, Campino L, Canavate C, Dedet JP, Gradoni L, Soteriadou K, et al Spread of vector-borne diseases and neglect of Leishmaniasis. Emerg Infect Dis 2008; 14:1013-1018.

24. Silva AR, Tauil PL, Cavalcante MNS, Medeiros MN, Pires BN, Gonçalves EGR. Situação epidemiológica da leishmaniose visceral, na Ilha de São Luís, Estado do Maranhão. Rev Soc Bras Med Trop 2008; 41:358-364.

25. Carranza-Tamayo CO, Carvalho MSL, Bredt A, Bofil MIR, Rodrigues RMB Silva $\mathrm{AD}$, et al. Autochthonous visceral leishmaniasis in Brasília, Federal District, Brazil. Rev Soc Bras Med Trop 2010; 43:396-399.

26. Oliveira ALL, Paniago AMM, Dorval MEC, Oshiro ET, Leal CR, Sanches M, et al. Foco emergente de leishmaniose visceral em Mato Grosso do Sul. Rev Soc Bras Med Trop 2006; 39:446-450. 
27. Alvarenga DG, Escalda PMF, Costa ASV, Monreal MTF. Leishmaniose visceral: estudo retrospectivo de fatores associados à letalidade. Rev Soc Bras Med Trop 2010; 43:194-197.

28. Michalsky EM, Fortes-Dias CL, França-Silva JC, Rocha MF, Barata RA, Dias ES. Association of Lutzomyia longipalpis (Diptera: Psychodidae) population density with climate variables in Montes Claros, an area of American visceral leishmaniasis transmission in the state of Minas Gerais, Brazil. Mem Inst Oswaldo Cruz 2009; 104:1191-1193.

29. Ministério da Saúde. Portaria Interministerial $n^{\circ} 1.426$, de 11 de julho de 2008. Proíbe o tratamento de leishmaniose visceral canina com produtos de uso humano ou não registrados no Ministério da Agricultura, Pecuária e Abastecimento e dá outras providências. Diário Oficial da União. 2008 - [cited 2010 Dec 12]. Available from: http://bvsms.saude.gov.br/bvs/saudelegis/gm/2008/ pri1426_11_07_2008.html.

30. Borges BKA. Fatores de risco para leishmaniose visceral em Belo Horizonte. [master's dissertation]. [Belo Horizonte]: Escola de Veterinária. Universidade Federal de Minas Gerais; 2006. 104 p. 